hydroxide. Combustion, 0.12 .38 gram substance gave 0.3005 gram $\mathrm{CO}_{2}$. This analysis gave: $\mathrm{C}, 66.2 ; \mathrm{H}, 6.6$. Calculated for $\mathrm{C}_{13} \mathrm{H}_{16} \mathrm{O}_{4}: C$, 66. I: $\mathrm{H}, 6.8$.

Conclusions.-(1) The data here given show that succinic derivatives, made by reactions that leave no doubt as to their composition, are different compounds from the isomers described in the foregoing article. Hence these latter are in all cases glutaric derivatives.

(2) Sodium benzyl cyanide resembles sodium cyanacetic ester in its action with aldehyde cyanhydrines. As in the case of the deportment of benzyl cyanide with cinnamic ester, so here also there is a tendency toward partial saponification. Having determined the deportment of benzyl cyanide in this respect, since we were using benzyl cyanide in the synthesis of alkyl glutaric and succinic acids when the article by Higson and Thorpe appeared, it is not our intention to make any closer approach to the freld of work of thorpe and his pupils.

CHEMICAI, I,ABORATORY,

'THE LNIVERSTTY OI" NHISRASKA, IANCOLN.

\title{
INFLUENCE OF FERTILIZERS UPON THE COMPOSITION OF WHEAT.
}

BY HARRY SNYDER.

Received January 23. 1908 .

There are a number of factors which are known to materially influence the composition of wheat as (1) secd, (2) soil, (3) climatic conditions, and (4) storage. These hare been studied by a number of investigators, and in general it can be said that while the composition of wheat, like that of all seeds, is fairly constant it is possible by increasing the fertility of the soil, by seed selection. control of the soil moisture, systematic cultivation or irrigation, and by control of the chemical changes incident to storage to favorably influence its composition and nutritive value.

In order to study the infuence of fertilizers upon the composition of wheat, sixty samples grown at 12 different localities in Minnesota and fertilized with different kinds of fertilizers were analyzed. At each of the twelve different places where the fertilizer tests were made a uniform piece of land was selected and five quarter acre plots were staked off. Fach plot received similar treatment as to cultivation and seeding. (In one of the plots no fertilizer was used and on the renaining plots, complete, potash, superphosphate and nitrogen fertilizers were applied. The grain from each of the plots was harvested and threshed separately, and bushel samples were shipped to the Chemical Laboratory of the Minnesota Expcriment Station for analysis and milling and technical tests.

Influence on Physical Qualities of Grain,--In many instances the fer- 
tilizers exerted some special influence upon the growth of the crop, e. g., nitrogen used alone retarding maturity, and minerals used alone hastening maturity. In some cases size and character of the kernels were influenced by the fertilizers. Larger, better filled, and better colored grain generally, resulted from their use, particularly where the fertilizers perceptibly increased the yield. In eight trials the phosphate fertilizers increased the weight of the grain per bushel and in two trials the weight was the same as when no fertilizer was used. In five trials potash increased the weight per bushel and in no case was the weight decreased by the application of potash. In some cases the nitrogen fertilizer increased and in other cases decreased the weight. In general, the heaviest weight and best quality of wheat was produced on the fertilized plots. In some of the tests, the phosphate, and in others the potash fertilizer exercised the greatest influence upon the quality of the grain, as to weight per bushel and uniformity of kernels. Nitrogen alone did not exert as great an influence toward improvement of the kernels as the mineral elements alone; in a few instances, however, nitrogen alone improved the glutenous character and general appearance of the grain.

From the tests made upon the different soil types of the state.it would appear that fertilizers may improve the quality of the grain, but the kind of fertilizer element as potassium, or phosphorus required for purposes of improvement depends entirely upon the individuality of the soil on which the wheat is grown. Improvement in quality of the grain follows as a result of increase in the fertility of the soil, and a soil nust be built up in the elements it lacks and these must be ascertained by experiments. In many localities where these experinents were made the climatic conditions were unfavorable, but it was noted that with the more liberal supply of plant food in the fertilized plots the quality of the grain as to weight per bushel, plumpness, maturity, and unifornity of kernels was better than on the unfertilized plots. This would indicate that during unfavorable seasons crops produced upon soils of low fertility are more susceptible to the adverse climatic conditions than crops grown upon soils of high fertility.

InFLUENCE OF FERTILIZERS UPON THE COMPOSITION OF WhEAT--Average COMPOSITION.

No. of Moisture. N N $6^{0 \%}$. extract. frude $\begin{array}{r}\text { Nitrogen- } \\ \text { fiber. Ash, free extract }\end{array}$

Kind of fertilizer. samples, Per cent. Per cent. Per cent. Per cent Per cent. Percent.

\begin{tabular}{|c|c|c|c|c|c|c|c|}
\hline Nitrogen. . & 12 & 10.03 & 13.63 & 2. I5 & 2.74 & I. $5^{8}$ & 69.87 \\
\hline Potash.......... & 12 & IO 24 & 13.02 & 2.10 & 2.65 & 1.62 & $f=0$ \\
\hline Phosphoric acid . . . . . . . . & I 2 & 10.39 & 12.65 & 2.19 & 2.73 & 1.73 & 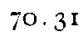 \\
\hline Complete $\left(\mathrm{N}, \mathrm{K}_{2} \mathrm{O}\right.$ and $\left.\mathrm{P}_{2} \mathrm{O}_{0}\right)$ & I2 & IO. I 5 & 13.17 & 2.22 & $2 \cdot 76$ & I. 69 & \\
\hline No fertilizer. . . . . . . . . & I2 & IO. I 6 & I 3.04 & $2.1 \mathrm{I}$ & 2.72 & I. 64 & \\
\hline
\end{tabular}

In all of the individual tests except one, the highest percentage of nitrogen was secured from the wheat grown upon the plots receiving 
either nitrogen alone or the complete fertilizer of which nitrogen formed a part. A similar result was secured in 1905 from a more limited number of trials. Increasing the supply of nitrogen in the soil slightly increased the amount of nitrogen in the grain. As previously noted, this increase in nitrogen alone, unless associated with the mineral elements, may result in a poorer quality of grain, for while nitrogen alone increased the crude protein content of the grain, to secure improvement in quality as well, the nitrogen must be associated with the other essential elements of plant food. The results indicate that in many cases it is possible to increase the protein content of wheat one per cent. or more through the use of fertilizers, also to secure an improvement in quality, although the average increase in protein was small.

The influence of the nitrogenous fertilizers upon the form of the nitrogen in wheat was also studied. A number of investigators have reported the presence of nitric nitrogen in plants. King and Whitson, in the Eighteenth Annual Report of the Wisconsin Experiment Station, page 220 , state that in the case of oats in the "milk stage" grown on soil very rich in nitrates, 2.64 per cent. of nitrogen was obtained by the ordinary Kjeldahl method, but when the method was modified to include nitrates, 3.12 per cent. was obtained. They also report nitric nitrogen in corn and potatoes.

For the purpose of determining the amount of nitric and other forms of nitrogen in the wheat fertilized with nitrate of soda, three samples were selected; wheat grown on University Farm, in the central western and in the southwestern part of the state. The results of the analyses are given in the following table:

Forms of Nitrogen in Wheat Fertilized with Nitrate of Soda.

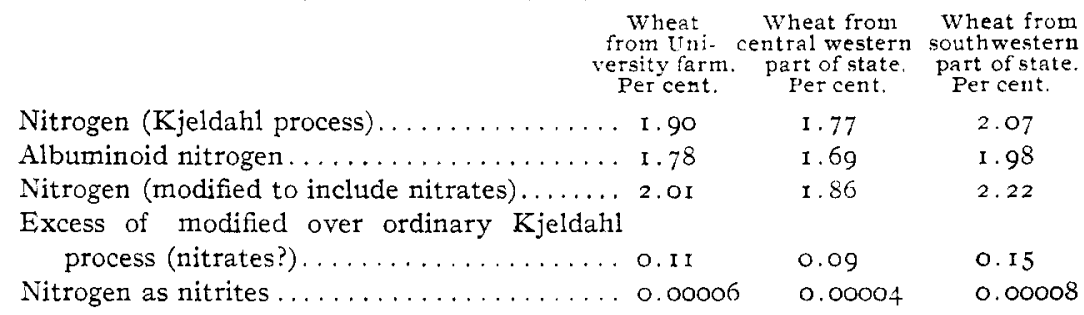

The difference between the nitrogen obtained by the modified and by the ordinary Kjeldahl process can not all be considered as nitric nitrogen but when the nitrate of soda was used as a fertilizer a small amount of nitric nitrogen was found by qualitative tests to be present in the wheat. The albuminoid nitrogen and the modified nitrogen determinations show that not all of the nitrogen in the plant was present as proteins. Qualitative reactions of all of the flours made from the wheats fertilized with nitrate of soda and organic nitrogen showed the presence 
of nitric nitrogen and also traces of nitrites. Some of the wheats grown upon the plots where there was no nitrogen in the fertilizers gave the same reactions, while others did not. The nitrogen content of the wheat was slightly increased by applications of nitrogenous fertilizers to the soil, but as previously stated the bread-making qualities of the flour from such wheat are not necessarily improved. Similar results have been reported by Hall, of the Rothamsted Station: "Again, as we have seen, 'strength' is generally associated with a high nitrogen content, yet the wheats grown on some of the Rothamsted plots, where so large an excess of nitrogenous manure is applied that even the grain becomes more nitrogenous, instead of becoming stronger only gets incredibly weaker."-Journal of the Board of Agriculture, September, 1904, page 332. It is quite evident that the form as well as the amount of nitrogen must be taken into consideration in studying the bread-making qualities of flour.

Infuence on Bread-making Value.-Forty-one of the sixty samples of the wheat were milled at the experimental flour mill of the Minnesota Experiment Station. The protein content of the flour was determined, and technical bread-making tests were made by an experienced baker, accustomed to making tests for a large flour mill.

The wheat from three of the nine places, grown upon the plots fertilized with phosphates, produced flour that made the best bread. From two of the places the wheat fertilized with nitrogen made the best bread; from two fertilized with potash, and from two the complete fertilized wheat.

In thirty of the forty-one tests the fertilizers which gave the largest yields per acre produced wheats of the highest bread-making value, while in ten of the tests the best quality of flour was secured from the fertilized wheats which did not show the largest yield per acre. While yield and bread-making quality are both improved by the use of fertilizers they are not necessarily both improved to the same extent by the same fertilizer.

There appears to be no constant relationship between the per cent. of protein in the grain and flour, and the bread-making value, and while it is possible to increase the amount of protein in flour by the use of nitrogenous fertilizers the bread-making value of the flour is not proportionally increased. In many instances the increase in nitrogen content imparted a negative value.

The experiments taken as a whole show that not only the yield of wheat, but also the bread-making value can be enhanced by increasing the fertility of the soil, and that there is a very close relationship between the amount of available plant food in the soil, and the quality of the 
wheat produced upon that soil and its bread-making value. Credit is due Mr. L. O. Bernhagen for assistance rendered in the analytical work.

AGRICULTURAL EXPERIMENT STATION,

ST. PaUL, MINA.

\section{THE PRECIPITATION METHOD FOR THE ESTIMATION OF OILS IN FLAVORING EXTRACTS AND PHARMACEU- TICAL PREPARATIONS.}

by Charles D. HOWARD.

Received Februaty 6, 1904.

The polariscopic method for the estimation of essential oils in commercial extracts is of but limited application, the oils of lemon and orange being the only ones that can be accurately determined in this manner. For the estimation of such oils as peppermint, clove, wintergreen, and many others, two procedures are open: (a) the application of methods for the estimation of the most important constituents of these oils, such as menthol, eugenol, or methyl salicylate, and $(b)$ the method by precipitation as suggested by Mitchell ${ }^{1}$ and now adopted with modifications as official by the A. O. A. C.

In most instances the first procedure, as applied to extracts, is obviously capable of affording but little better than a general idea as rcgards strength or quality, while results by the second process involve the application of a large and variable correction. Thus, in the case of lemon oil Mitchell ${ }^{2}$ found that results near to the truth were obtainable only in the presence of a relatively large proportion of oil-a 6 per cent. extract, for instance, showing 4.80 per cent. recoverable, while a 2.50 per cent. extract afforded by this procedure less than one-half of the oil actually present.

With a less proportion of oil the error becomes still greater, and when we consider in addition that this error apparently varies not only with the quantity of oil, but with the kind, it is evident that for the examination of many of the miscellaneous extracts and essences now on the market-many of them containing as they do but one or two per cent. of oilthe method as at present carried out is of but very limited value. This fact will be appreciated by any who has attempted to examine some of the cheaper grades of peppermint essence.

By the modified method here proposed the writer has obtained nost excellent results. The procedure has the advantage that no correction whatever for oil retained in solution is necessary, and moreover, with the single exception of almond extract, it affords equally accurate results in the case of alcoholic solutions of almost any one of the large

1 THIS JOURNAL, 2 r, II 32 (I 899 ).

${ }^{2}$ Loc. cit. 